\title{
Downward Mobility: When Social Lifts Change Direction Maxim Chupilkin
}

\author{
https://doi.org/10.22151/politikon.41.4
}

Maxim Chupilkin from Moscow (Russia), is an undergraduate student at New Economic School and Higher School of Economics. Planned year of graduation is 2020. He currently interns at Carnegie Endowment for International Peace Moscow Center and works at The Political Economy research group. His interests include social and political anthropology, protest dynamics, democratic transition and wealth inequality.E-mail:mchupilkin@,nes.ru

\begin{abstract}
In this research note, a new direction in the study of inequality is being advocated. The current research in the field of social mobility is extensively focused on upward mobility and pays no attention to downward mobility. With the help of intergenerational wealth data, this contribution demonstrates the unexplained questions of downward mobility, shows the importance of studying children from both poor and privileged backgrounds and outlines possible research directions in the field. This research note is a call for action for scholars of inequality.
\end{abstract}

\section{Keywords}

Capital Accumulation; Income; Inequality; Intergenerational Inequality; Social Mobility; Wealth 


\section{Introduction}

Inequality is one of the most discussed problems in the field of social sciences. Inequality of income and inequality of wealth, inequality and democracy (Bartels, 2008), intergenerational inequality (Corak, 2013) — the problem of inequality encompasses many broad topics and is perhaps one of the most multi-disciplinary problems in the scholarly world. The study of inequality originally reserved for the universities and think-tanks is now influencing public opinion and policy making.

The impact of the discussion around inequality on the state of affairs in the real world makes it even more urgent to find drawbacks and blind spots in the existing debates. One of the biases in the study of inequality is that the current literature is extensively focused on the upward mobility and constraints for the economic performance of the low-income youth - the main example would be the discussion started by the work of the economist Thomas Piketty (Piketty and Goldhammer, 2014). The field has omitted the fact that mobility is usually a two-way process: if somebody goes up, someone else has to go down. The typical question asked by the research is "how can we explain why a child born in the lowest quintile of the income distribution has a low probability of getting into the highest quintile?" This research note also makes a case for studying why and how youth from the privileged families move down the social and economic ladder. Firstly, the problem in statistics of intergenerational wealth and income inequality is identified. In the further sections, implications of the concept are developed and ideas for future research are made.

This research note pursues two contributions to Political Science. Firstly, it broadens the optics used to study inequality and mentions consequential policy-making implications. Secondly, it raises the question about the impact of institutions — if the access to the best schooling, healthcare and infrastructure guarantees success on the income ladder with almost the same efficiency as the flip of a coin, what is the real role of institutions in the financial success of the individual?

\section{Note on existing research}

The problem of inequality is intrinsic to the neoliberal economic system which is the dominant approach of today's policy-makers (Alfredo et al., 2005). What is more important for this study - specifically downward mobility is one of the philosophical foundations on which neoliberalism is built. Contemporary economics appraise the approach of Schumpeterian creative destruction - big companies are forced to step down by disruptive startups (Schumpeter, 1942). This can be broadened to the whole economic structure of the society — the old and inefficient should be brought down by the young and dynamic. This is downward mobility in its essence industrial magnates were replaced by the Silicon Valley, middle class factory workers by programmers and designers, cinemas by Netflix. 
The problem of downward mobility is neglected. Major scholars of inequality focus on how wealthy groups create political and economic systems that protect the rich while excluding the poor (Stiglitz 2015, Bartels 2008). This study shows that downward mobility exists and should be studied. Despite making rules work in their favor rich families still face high risks of moving down the wealth ladder.

There are several studies of the downward mobility which show that, firstly, privileged classes do tend to lose status and power and, secondly, that after the loss prestige is not easily gained back. This is present in different countries and economic systems - American middle-class (Newman, 1999), kids of the Maoist middle class in the changing China (Davis, 1992), refugees and migrants (Gans, 2009), previously non-poor families in rural Uganda (Bird and Shinyekwa, 2005). These findings show that downward mobility is a problem as well and can have a significant economic and emotional cost. This research note advocates that downward mobility can be shown on the crossgenerational income and wealth data in the US. The significant probability of the downward mobility and the associated costs make it even more urgent to broaden the research of inequality to explain why the downward mobility occurs.

\section{The unexplained statistics}

Sixteen years ago, Charles and Hurst (2003) computed the correlation of wealth across generations. They did so in the research on the US households, having taken the date from the Panel Study of Income Dynamics, the survey of the socio-economic status since 1968. The sample used by the authors includes all the families in which in 1999 a child had at least one core sample parent known to be alive and both parents and children have positive wealth in the years measured. This results in 1491 parent-child pairs observed. Charles and Hurst calculate a regression of the log of children's wealth on the log of parents' wealth. This study is already not up to date; however, it suits well to illustrate the blind spot in the study of inequality. Charles and Hurst show that a child born in the first (lowest) quintile of wealth distribution as an adult has a 65\% chance to be in the first or second quintiles and 19\% chance to end up in the 4th and 5th quintiles of the wealth distribution. They also show that the child born in the fifth quantile of wealth distribution has a $60 \%$ chance to be in the fifth or fourth quintile of the distribution.

Most of the research on inequality is focused on explaining the first observation: schools which are reproducing the intergenerational poverty (Corcoran, 1995), inefficient parenting (McLanahan and Sandefur, 1994) and lower cognitive skills (Doren and Grodsky, 2016). At the same time, there is no research that explains why children born in the wealthiest families (fifth quintile) have a $40 \%$ chance to end up in the third quintile or lower. Their chances of getting to the lowest quintile of wealth distribution are $11 \%$ (Charles and Hurst, 2003). 
Similar statistics can be observed in the income distribution. In a recent significant study of income inequality and race conducted jointly by Stanford, Harvard, and U.S. Census Bureau scholars, the authors performed the analysis of the longitudinal U.S. Census Bureau data on the whole American population from 1989 to 2015 focusing on income dynamics across generations. Information on income, race and other factors was obtained from American Community Surveys 2005-2015. The primary analysis sample of the authors includes 20 million children. The research shows that White children born in the fifth quintile have a $41.1 \%$ chance to stay there, Black 18\%, Asian - 48.9\%, Hispanic - 30.6\%, American Indian - 23\% (Chetty et al., 2018). These numbers highlight not only the racial disparities but also the unexplained mechanism of the downward social lifts. Why do kids even from the most privileged groups have less than $50 \%$ chance to stay in the privileged state?

This problem can be summed up as that of the mechanism of downward social mobility. The contemporary scholarship of inequality has a gap in understanding which factors influence the movement of the person down the income and wealth ladder. This blind spot can cause bias in both scholarship and policy making. The studies used as examples focus on the United States; however, as the point of this research note is to show the limitations of contemporary scholarship of inequality rather than to make empirical conclusions about the problem, the US data serves as a good example. The next part of this research note explores, firstly, what are the implications of the downward social mobility and, secondly, what research can be conducted in this field.

\section{Implications of the downward mobility}

Downward social mobility calls into question the philosophical foundations of our society. In both academy and policy-making there is an assumption that children from wealthy families have a guarantee of success in the future. In the review of the debates on wealth inequality Killewald, Pfeffer and Schachner (2017) write:

Parental wealth is associated with greater offspring educational and cognitive achievement (Conley 1999, 2001a; Doren \& Grodsky 2016; Friedline et al. 2015; Jez 2014; Orr 2003; Pfeffer 2011; Yeung \& Conley 2008) and labor market outcomes, such as occupational attainment and work hours (Conley 1999, Pfeffer 2011).

The same logic is present in the OECD Centre for Opportunity and Equality (2017) reports which can serve as a proxy of what ideas are guiding the policy-making in the countries:

Children from more affluent families tend to develop better skills in reading and problem solving, are less likely to drop out of school without a diploma, and are more likely to complete tertiary education. 
Though being so privileged, these kids still have less than $50 \%$ chance of replicating the financial success of their parents — this is a paradox. Kids of the parents from the highest quintile of the wealth or income distribution have access to the best institutions of our society: best education at all levels, best healthcare, best methods of parenting, best housing, best infrastructure broadly. Research even shows the developed advantage in cognitive skills. Nevertheless, after getting all the best of the best institutions, they have a less than $50 \%$ chance to have income as high as their parents.

Both academic literature and policy recommendations show that in the debate about inequality the goal of social mobility is always to give the kids from poorer background opportunities similar to the affluent children. In this logic, there is an implicit statement that the goods that the kids from rich families were lucky to get from birth secured for them high levels of success in the future life. Data shows that this assumption is not as solid as it is often supposed to be.

Our society is based on the belief in the power of human-designed institutions to influence the outcomes. Otherwise, it would be pointless to debate the merits of any political order, educational system or healthcare policy. The goal of the institutions is to tackle nature by nurture. This is important for the aspect of justice. Any theory of justice is arguing for the independent criterion — be it the highest utility for all (Bentham, 1781), equality of basic liberties (Rawls, 1985) or equality of basic capabilities (Sen, 1980) — on which the institutions should be created. In any discussion about justice there is an implicit assumption that the better the institution the higher the opportunity to have a prosperous life. If being treated by the best institutions in all aspects of life from the early childhood still leave a $50 \%$ probability of not being in the top $20 \%$ of financially successful citizens - the role of the institutions is somewhat exaggerated.

Research on these questions may have wide policy implications. Currently, the anti-inequality policy is focused on providing better access to institutions such as healthcare or education. For example, OECD policy recommendations are interventions in the field of education, labor market, urban planning, healthcare and parenting (Social Mobility and Equal Opportunities, 2017). But if the best institutions do not guarantee the place in the highest-earners, the policy which tackles inequality and promotes mobility should be aimed at something different.

Studying downward social lifts may offer valuable insights into the problem of inequality itself. In order to understand mobility, the best strategy is to understand both directions, while the current research is noticeably biased towards understanding upward mobility. Such research can uncover new factors which influence both upward and downward mobility — social network, consumption behavior, status. Upward and downward inequality are happening simultaneously. The research into only one of two types of lifts may create biases while studying both directions helps avoid at least some of them. 
The proposed research can be useful for better understanding the dilemma of social mobility. Social mobility is by its nature a zero-sum game. Everyone can't be in the top $20 \%$ of the income distribution and $20 \%$ of the population have to be in the poorest $20 \%$. When more comparatively poor children become comparatively rich adults, the more comparatively rich children become comparatively poor adults. In any case, the children from the privileged background should not be punished for the opportunities they had in the childhood. The goal of tackling inequality is to make access for resources provided by merit or other just criterion and not by privileging or denying the privilege to any background: rich or poor. The lack of study of the children from the rich background excludes them from the discussion about inequality and therefore can lead to policy bias as well.

\section{Avenues for further research}

There are several research directions in the study of downward social mobility. Some of these are outlined as examples.

The interesting fact about children from the very rich background is that their problems may be mirrored problems of kids from the very poor background. Corcoran and Goertz showed that schools reinforce the problem of poverty among children (1995). The perverse effect of schooling may also be visible in the privileged kids. Children of rich parents often study in closed communities and have almost no contact with people from other circles. As a result, they study in the closed system which reinforces all the problems of the social group "rich kids". There is no contact with the outside world which could have had eradicated the inefficient norms. In the study of the childhood poverty Lichter (1997) writes:

A growing policy concern is whether the increasing geographic concentration of poverty in lowincome urban neighborhoods or rural areas promotes maladaptive behavioral or cultural adjustments—juvenile delinquency, school dropout, and nonmarital childbearing.

The same promotion of harmful practices may be happening in the closed rich communities. In both schooling and segregated neighborhoods very poor and very rich differ significantly from the middle class.

The second direction of study can be investment and consumption behavior. Charles and Hurst (2003) stress the important fact that children tend to have the same investment behavior as their parents. Children of rich parents may hold riskier assets, not because of the risk tolerance but by replicating the behavior of successful parents. These practices may have bad consequences risky investment strategy, though efficient for the wealthy person, may be too risky for the young adult even from a privileged family.

Extrapolating the investment behavior on consumption, rich kids may continue the patterns of consumption adopted in childhood throughout the whole adult life. This can be a strong hit to 
the wallet in the time of being a young adult and can decrease savings and therefore make the individual more vulnerable for the financial stress.

The research on investment and consumption patterns is connected to the broad question of status. Affluent families transmit to the offspring the feeling of "high status" which can impact many decisions in the later life. Status can have an effect on consumption, job choice, family decisions. The privileged background may reinforce the behavior "beyond the means" for the child who is not supported by the family any longer but has not managed to accumulate her own wealth yet.

\section{Conclusion}

All in all, downward social mobility is significantly understudied in comparison with upward mobility. This gap is present in institutional analysis as well as the study of upward social lifts. Important insights about the structure of inequality and policy-making can emerge as a result of the proposed research program. The current situation can result in a bias in the scholarly discussion and policy-making. In order to tackle the problem of inequality, all its aspects deserve equal attention.

\section{References}

Alfredo, Saad-Filho and Deborah Johnson (2005): Neoliberalism: A Critical Reader. Chicago: University of Chicago Press.

Bartels, Larry M. (2008): Unequal Democracy: The Political Economy of the New Gilded Age. Princeton, NJ: Princeton University Press.

Bentham, Jeremy (1789): An Introduction to the Principles of Morals and Legislation. Oxford: Oxford University Press. DOI: https://doi.org/10.1093/oseo/instance.00077240

Bird, Kate and Isaac Shinyekwa (2005): 'Even the 'Rich' are Vulnerable: Multiple Shocks and Downward Mobility in Rural Uganda', Development Policy Review 23(1), pp. 55-85. DOI: https://doi.org/10.1111/j.1467-7679.2005.00276.x

Chetty, Raj. et al. (2018): 'Race and Economic Opportunity in the United States: An Intergenerational Perspective', NBER Working Paper No. 24441. DOI: https://doi/org/10.3386/w24441

Corak, Miles (2013): 'Income Inequality, Equality of Opportunity, and Intergenerational Mobility', Journal of Economic Perspectives 27 (3), pp. 79-102. DOI:

https://doi.org/10.1257/jep.27.3.79

Corcoran, Thomas and Margaret Goertz (1995): 'Instructional Capacity and High Performance Schools, Educational Researcher 24(9), pp. 27-31. DOI: https://doi.org/10.3102/0013189X024009027 
Doren, Catherine and Eric Grodsky (2016): 'What Skills Can Buy: Transmission of Advantage through Cognitive and Noncognitive Skills', Sociology of Education 89(4), pp. 321-342. DOI: https://doi.org/10.1177/0038040716667994

Gans, Herbert J. (2009): 'First Generation Decline: Downward Mobility Among Refugees and Immigrants', Ethnic and Racial Studies 32(9), pp. 1658-1670. DOI: https://doi.org/10.1080/01419870903204625

Charles, Kerwin K. and Erik Hurst (2003): ‘The Correlation of Wealth across Generations', Journal of Political Economy 111(6), pp. 1155-1182. DOI: https://doi.org/10.1086/378526

Killewald, Alexandra et al. (2017): 'Wealth Inequality and Accumulation', Annual Review of Sociology 43, pp. 379-404. DOI: https://doi.org/10.1146/annurev-soc-060116-053331

Lichter, Daniel T. (1997): 'Poverty and Inequality Among Children', Annual Review of Sociology 23, pp. 121-145. DOI: https://doi.org/10.1146/annurev.soc.23.1.121

McLanahan, Sara and Gary Sandefur (1994): Growing Up with a Single Parent: What Hurts, What Helps. Cambridge: Harvard University Press.

Newman, Katherine (1999): Falling from Grace: Downward Mobility in the Age of Affluence. Berkeley: University of California Press.

OECD Centre for Opportunity and Equality (2017): Conference Issues Note. The Only Way is Up? Social Mobility and Equal Opportunities. Paris: OECD Publishing.

Piketty, Thomas and Arthur Goldhammer (2014): Capital in the Twenty-first Century. Cambridge: The Belknap Press of Harvard University Press.

Rawls, John (1985): 'Justice as Fairness: Political Not Metaphysical', Philosophy and Public Affairs 14(3), pp. 223-251.

Sen, Amartya (1980): 'Equality of What?' in McMurrin, Sterling M. (ed.) Tanner Lectures on Human Values. Cambridge: Cambridge University Press.

Schumpeter, Joseph A. (1942): Capitalism, Socialism and Democracy. New York: Harper \& Row.

Stiglitz, Joseph E. (2015): Rewriting the Rules of the American Economy: An Agenda for Growth and Shared Prosperity. New York: W.W. Northon \& Company, Inc 